\title{
Protein malnutrition and gastro-intestinal histamine in the rat
}

\author{
By L. I. L. NDIKA* \\ Department of Pharmacology, College of Medicine of the \\ University of Lagos, PMB i 2003, Lagos, Nigeria, and \\ Department of Pharmacology, University of Melboume, \\ Parkville, Victoria 3052 , Australia
}

(Received ro December I971 - Accepted 20 fanuary 1972)

\begin{abstract}
I. The effects of high-protein ( $20 \%$ casein), low-protein ( $2 \%$ casein) and protein-free diets, given forcibly and $a d$ lib., were studied in male weanling and adult rats.

2. The influence of dietary protein on the concentrations of histamine in the gastro-intestinal tract was also investigated.

3. With ad lib. feeding, when food consumption was calculated as the amount of food eaten per $100 \mathrm{~g}$ rat there was no statistically significant difference between the amount of food eaten ( $11.05 \pm 0.28 \mathrm{~g}$ ) by rats on the high-protein diet and the amount consumed (10.65 $\pm 0.42 \mathrm{~g}$ ) by rats on the protein-free diet $(P<0.5)$. Rats fed on the low-protein diet had significantly lower food $(P<0.0 \mathrm{I})$ and calorie $(P<0.00 \mathrm{I})$ intakes than did rats on the protein-free diet.

4. 'The pathological lesions and other symptoms produced in rats on the low-protein or the protein-free diet were closely similar to those of kwashiorkor in children.

5. In the force-fed group of rats the concentration of histamine in the ruminal stomach was unaffected by any of the dietary regimens, but the concentration in the glandular stomach was slightly reduced by each of the experimental diets irrespective of its protein content. In rats fed ad lib. on the low-protein or on the protein-free diet the histamine concentrations of both the ruminal and the glandular stomach were elevated. In some rats these increases were associated with petechial gastric ulcers. The histamine concentration in the ileum was not altered by any of the diets, whether given $a d$ lib. of forcibly.

6. When rats on the protein-deficient diets were rehabilitated on a normal laboratory rat diet the pathological lesions and other associated symptoms were reversed within $14-2 \mathrm{I}$ and the elevated gastric histamine concentrations fell to normal within $\mathrm{I}_{4} \mathrm{~d}$.
\end{abstract}

Numerous attempts have been made to mimic human kwashiorkor in experimental animals by feeding them with low-protein or protein-free diets (Platt, Halder \& Doell, I962; Platt, Heard \& Stewart, I964; Kirsch, Brock \& Saunders, I968). In their studies of the effects of protein-deficient or amino acid-deficient diets, various workers (Adamstone \& Spector, I950; Spector \& Adamstonc, I950; Samuels, Goldthorpe \& Dougherty, I95I; Van Pilsum, Speyer \& Samuels, 1957; Sidransky \& Faber, 1958; Sidransky \& Rechcigl, 1962) have used force-feeding as opposed to ad lib. feeding to obviate the depression of food intake reported to occur when animals are allowed free access to low-protein or protein-free diets (Platt et al. 1964; McCance \& Widdowson, I966; Kirsch, Brock \& Saunders, I968). Force-feeding is unphysiological, can induce hyperglycaemia with a rebound hypoglycaemia and may be traumatic.

As kwashiorkor is essentially a disease of childhood, the aim of this paper was to compare and contrast the effects of low-protein and protein-free diets, given both ad lib. and forcibly to weanling and adult rats.

* Present address: Department of Pharmacology, Faculty of Medicine and Pharmacy, University of Benin, Benin City, Nigeria. 
An additional purpose was to investigate the tissue histamine concentrations in experimental protein malnutrition. Histamine is an amine with widespread physiological activities and is derived from the amino acid, histidine.

The gastro-intestinal tract was chosen as a starting-point because its tissues have a high rate of protein turnover and are therefore affected early by protein deprivation. The physiological role of histamine in gastric function has been well substantiated, (Code, 1965 ), and in the rat the gastric mucosa is the richest source of histamine and has a much higher histamine-forming capacity than most other tissues (Kahlson, Rosengren, Svahn \& 'Thunberg, 1964).

\section{EXPERIMENTAL}

\section{Animals}

Male albino rats of the Wistar strain were used. The adult rats weighed between 200 and $250 \mathrm{~g}$. The immature rats were weaned at $2 \mathrm{I} \mathrm{d}$, by which time their weights varied between 45 and $60 \mathrm{~g}$, and were immediately used in the experiments. In the ad lib.-fed rats, nine animals per nutritional group were used and thirteen rats per nutritional group were used in those fed forcibly.

\section{Diets and feeding}

The rats were fed with high-protein, low-protein or protein-free diets or with ground laboratory chow. They were placed in cages, each usually holding nine or thirteen rats, and housed at an ambient temperature of $23 \pm 1^{\circ}$. The composition of the diets and their respective calorie and protein contents, as determined by analysis, are shown in Table 1 . With the exception of laboratory chow, the diets were prepared for force-feeding as follows: the salt mixture, vitamin mixture, casein and sucrose were triturated in this order with a pestle and mortar. The maize oil was added and the mixture triturated to homogeneity. The mixture was then homogenized with warm tap-water and made up to volume so that Io $\mathrm{ml}$ of the resultant emulsion contained $5 \mathrm{~g}$ of the dietary constituents. The diets were prepared daily and kept warm through the day by leaving them in a warm water-bath. Rats were force-fed with these diets, using the method of Shay \& Gruenstein (1946), at the rate of $10 \mathrm{ml} / \mathrm{I} 00 \mathrm{~g}$ body-weight three times a day (at approximately $08.00, \mathrm{I} 3.00$ and 18.00 hours). This corresponds to feeding at the rate of $\mathrm{I} 5 \mathrm{~g}$ food/roo $\mathrm{g}$ body-weight per $\mathrm{d}$, which under normal conditions is reported adequate to maintain satisfactory growth (Platt $e t a l$. 1962). Two control groups, fed on ground laboratory chow, were used. One of these was allowed free access to the food, and the other was pair-fed with the force-fed groups, their food intake being restricted to $15 \mathrm{~g} / \mathrm{roo} \mathrm{g}$ body-weight per $\mathrm{d}$.

For the rats fed ad lib. the diets were not emulsified with water. The dry dict mixtures were placed in cans and perforated discs were laid freely on top of the food to prevent spilling. The cans were then weighed, placed in the cages for $24 \mathrm{~h}$ and then weighed again, and the amount of food consumed was calculated by difference. Two groups of rats fed on ground laboratory chow served as controls in experiments in 
Table r. Composition of diets

\begin{tabular}{|c|c|c|c|c|c|c|c|}
\hline \multirow[b]{2}{*}{ Diets } & \multicolumn{7}{|c|}{ Amount in $100 \mathrm{~g}$ diet } \\
\hline & $\begin{array}{l}\text { Casein* } \\
\text { (g) }\end{array}$ & $\begin{array}{l}\text { Sucrose } \\
\text { (g) }\end{array}$ & $\begin{array}{l}\text { Maize } \\
\text { oil } \\
\text { (g) }\end{array}$ & $\begin{array}{c}\text { Salt } \\
\text { mixture } \dagger \\
\text { (g) }\end{array}$ & $\begin{array}{l}\text { Vitamin } \\
\text { mixture } \\
\text { (g) }\end{array}$ & $\begin{array}{l}\text { Protein } \\
\text { (g) }\end{array}$ & $\begin{array}{c}\text { Energy } \\
\text { value } \\
\text { (kcal) }\end{array}$ \\
\hline High-protein & 20 & 69 & 5 & 4 & 2 & $18 \cdot 4$ & 448 \\
\hline Low-protein & 2 & 87 & 5 & 4 & 2 & $\mathrm{I} \cdot 8$ & 402 \\
\hline Protein-free & $\circ$ & 89 & 5 & 4 & 2 & 0.0 & 415 \\
\hline $\begin{array}{l}\text { Laboratory rat chow } \\
\text { (control) }\end{array}$ & - & - & $\underline{-}$ & - & - & 19.8 & 398 \\
\hline
\end{tabular}

which rats were fed ad lib. One group had this diet in an unlimited amount; the other was pair-fed with those rats on the protein-free diet.

Water was given freely to all groups. Each rat was weighed daily before feeding and observations were made on the animal's behaviour throughout the experimental period.

\section{Extraction and biological assay of gastric and ileal histamine}

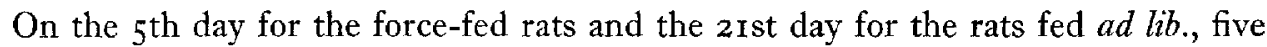
rats from each nutritional group were killed by cervical fracture. These periods were dictated by the increasing number of deaths among rats on the low-protein and protein-free diets. The stomach was dissected out and the ruminal portion was separated from the glandular stomach by cutting along the horizontal dividing ridge which extends from the greater curvature to the cardia: the glandular stomach comprises the fundic and the pyloric portions of the rat stomach (Lambert, 1965). Each section was opened, gently washed in physiological saline $(0.9 \%, \mathrm{w} / \mathrm{v}, \mathrm{NaCl})$ and dried between filter-papers. The pooled tissues were weighed. Portions of terminal ileum were also removed from the same rats, opened longitudinally, similarly washed, blotted, pooled and weighed. Histamine was extracted from these tissues by the method of Parratt \& West (1957). The extracts were assaycd biologically for histamine by means of the isolated guinea-pig ileum suspended in atropinized Tyrode solution bubbled with air. Four rats on the low-protein and four on the protein-free diets were rehabilitated on normal laboratory chow for $\mathrm{I} 4 \mathrm{~d}$, at the end of which the histamine contents of the ruminal and glandular stomachs and of the ileum were extracted and assayed.

\section{Histological examination}

At the same time that tissues were removed for extraction of histamine, specimens of liver were taken and fixed in $10 \%$ formol saline. Sections were stained with haematoxylin and cosin or with Sudan IV for fat. 


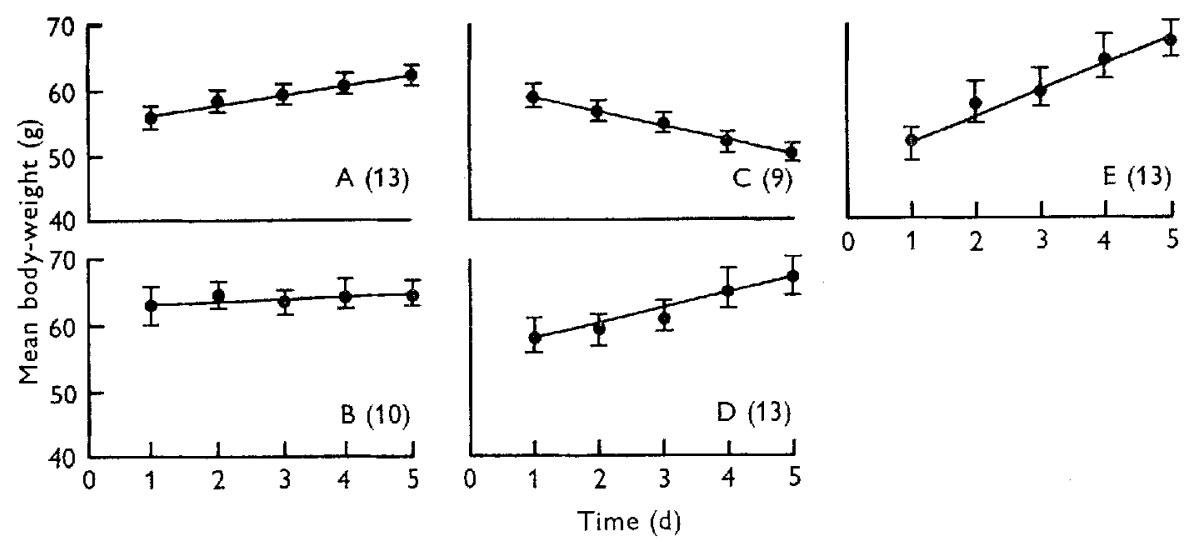

Fig. 1. Growth curves of weanling rats fed on diets of different protein content. With the exception of groups $\mathrm{E}$ and $\mathrm{D}$ the rats were force-fed. The number of rats per group is shown in parentheses. Regression equations: for (A) $Y=54 \cdot 68+x \cdot 49 x$; (B) $Y=6 z \cdot 96+0 \cdot 36 x$, (C) $Y=60.82-2 \cdot 36 x$, (D) $Y=54 \cdot 09+2 \cdot 42 x$, and for (E) $Y=47 \cdot 93+3.59 x$. The vertical bars represent the standard errors of the mean. (A) high-protein, (B) low-protein, (C) protein-free, (D) laboratory diet, pair-fed group, and (E) laboratory diet, ad lib.

\section{RESULTS}

Food intake and growth

Force-fed rats. Fig. I shows the weight changes in force-fed weanling rats and in the two control groups. There was a statistically significant difference between the weight gains of control rats fed $a d$ lib. on laboratory diet and the pair-fed control group on $\mathrm{I} 5 \mathrm{~g}$ laboratory chow/100 g body-weight per $\mathrm{d}(P<0.00 \mathrm{I})$, as well as between the gains of the former and those of rats force-fed with the high-protein diet $(P<0.001)$. Rats on the high-protein diet gained less weight than their pair-fed control partners on laboratory chow but the difference was not significant $(P<0.8)$. Rats on the low-protein diet did not gain weight and those on the protein-free diet showed a striking loss in body-weight.

In force-fed adult rats the rates of growth of the control groups and of rats on the high-protein diet did not differ significantly $(P<0.5)$ but in each instance were less than the corresponding rate in the weanling rats. Also the adult rats on the protein-free diet lost weight less precipitously than did the corresponding weanling rats. The rats on the low-protein diet, as did the weanling animals, merely maintained their bodyweight during the 5 feeding $\mathrm{d}$.

Rats fed ad lib. Fig. 2 shows how the various diets affected food consumption in weanling rats fed ad lib. for $2 \mathrm{I} \mathrm{d}$. This figure demonstrates that when the food of weanling rats is adequate in protein, food intake per rat increases (Fig. $2 a$ ) but the food intake per $100 \mathrm{~g}$ rat decreases (Fig. $2 b$ ) with age. In contrast, in rats given protein-deficient diets the food intake per rat gradually decreases (Fig. 2a) but the intake per $100 \mathrm{~g}$ rat remains appreciably unaltered by age.

Fig. 3 shows the mean daily intakes of food, protein and calories per $100 \mathrm{~g}$ bodyweight in weanling rats and the mean daily change in body-weight per $100 \mathrm{~g}$ rat throughout the $2 \mathrm{I} d$ of feeding. Control rats given unlimited amounts of laboratory 


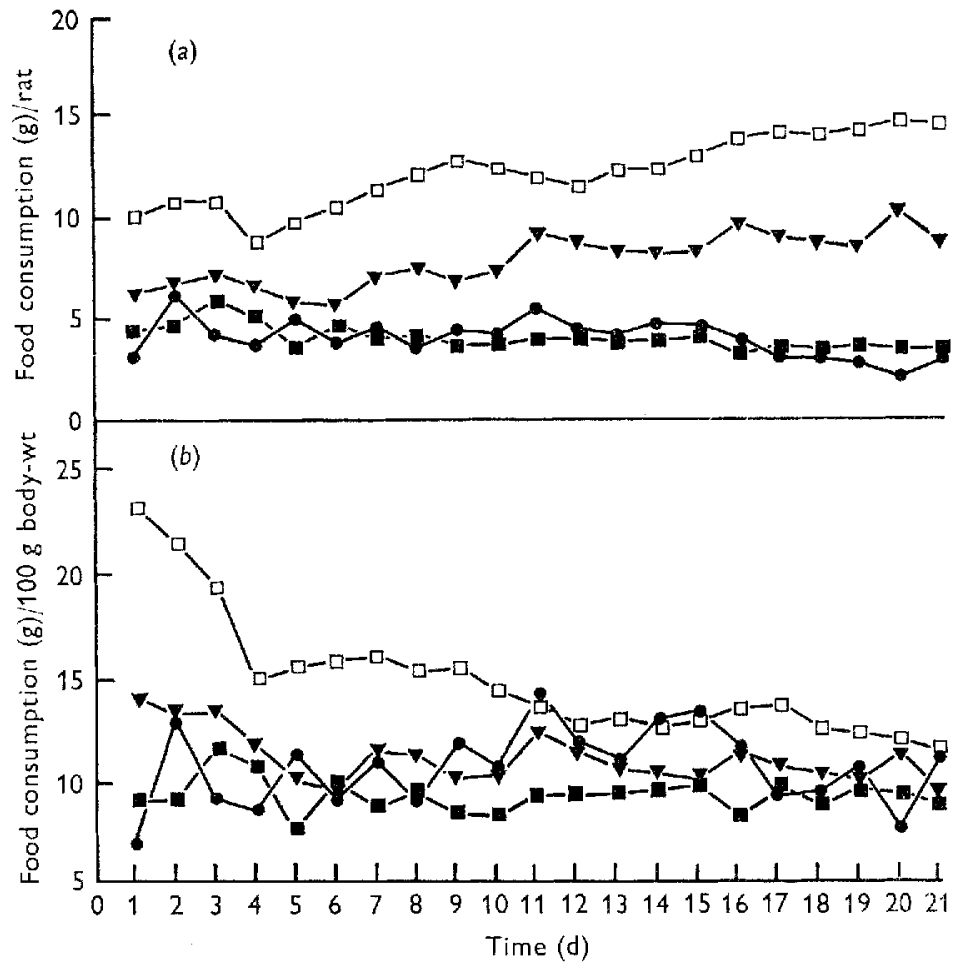

Fig. 2. Daily food consumption of weanling rats fed ad lib. for $2 \mathrm{I} \mathrm{d}$ on diets of different protein content expressed as $(a) \mathrm{g} / \mathrm{rat}$ and $(b) \mathrm{g} / \mathrm{/} 00 \mathrm{~g}$ body-weight. $\square-\square$, laboratory diet (control); $\mathbf{\nabla}-\mathbf{v}$, high-protein; $\mathbf{\square} \longrightarrow$, low-protein; $-\infty$, protein-free.

chow ate significantly more than those on the high-protein diet $(P<0.00 \mathrm{I})$ and had higher protein $(P<0.001)$ and caloric $(P<0.001)$ intakes but, despite these differences, the mean daily gain in body-weight between these two groups did not differ significantly $(P<0 \cdot \mathrm{I})$. The rates of food intake by rats on the high-protein and on the protein-free diets were not significantly different $(P<0.5)$ but the former group had a higher calorie intake $(P<0.02)$ than the latter. The calorie consumption of rats on the high-protein diet was greater than that of the control rats pair fed on laboratory chow with rats on the protein-free diet $(P<0$-or $)$ but the protein intake of the two groups was similar $(P<0.5)$. Rats on the protein-free diet had a higher, but not significantly so $(P<0.5)$ calorie intake than their pair-fed partners. Rats fed on the low-protein diet had significantly lower food $(P<0.01)$ and calorie $(P<0.00 \mathrm{I})$ intakes than did rats on the protein-free diet.

\section{Clinical findings}

Pl. I $A$ shows the appearances of two weanling rats, one on the high-protein diet and the other on the low-protein diet offered ad $l i b$. Similar appearances were presented by force-fed weanling rats and by adult rats fed ad lib. or forcibly. There were no signs of abnormalities in rats on laboratory chow or the high-protein diet. In contrast, the rats on the protein deficient diets presented with a number of abnor- 


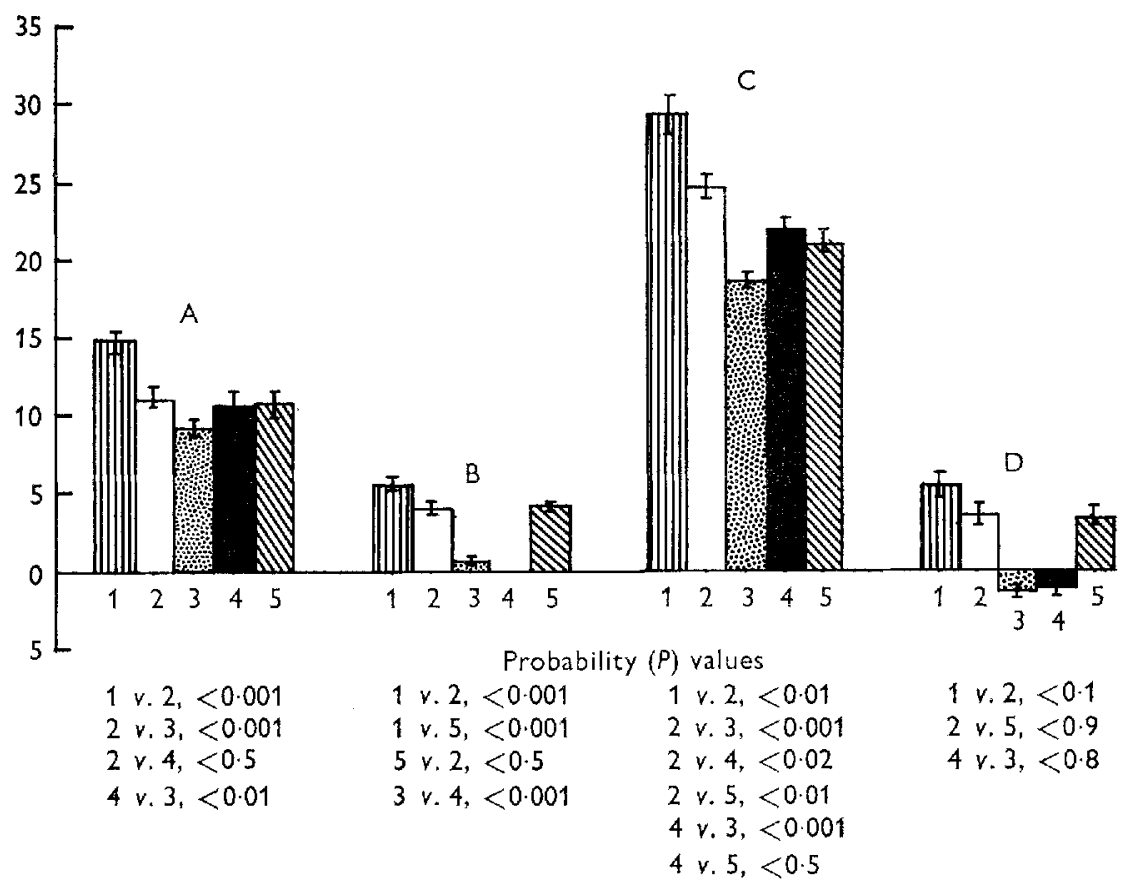

Fig. 3. Mean daily food, protein and calorie intakes per $100 \mathrm{~g}$ body-weight and mean daily percentage change in body-weight in weanling rats fed ad lib. for $2 \mathrm{I} d$ on diets of different protein content. Nine rats constituted a nutritional group. The vertical bars represent the standard errors of the mean. $\mathrm{A}$, mean daily food intake $(\mathrm{g}) / \mathrm{r} 00 \mathrm{~g}$ body-weight; $\mathrm{B}$, mean daily protein intake $(\mathrm{g}) \times 2 / 100 \mathrm{~g}$ body-weight; $\mathrm{C}$, mean daily calorie intake (kcal) $\times 0.5 / 100 \mathrm{~g}$ body-weight; $\mathrm{D}$, mean daily change in body-weight (g)/100 $\mathrm{g}$ body-weight. $\mathrm{I}$, laboratory diet (control); 2 , high-protein; 3, low-protein; 4, protein-free; 5, laboratory diet pair-fed with protein-free group.

malities in addition to growth failure. The hair in these rats became shaggy and rough with a spike-like setting, reminiscent of the appearance of iron filings in a magnetic field. The hair fibres were loosely attached to the skin, as evidenced by the ease with which they could be rubbed off and there was frank alopecia in many of these rats, especially around the neck and the dorsum.

Extensive skin lesions, especially of the tails, and severe oedema, mainly of the paws and the snout (PI. I B), were present in about $45 \%$ of the weanling rats fed $a d$ lib. on the protein-deficient diets. These lesions were not evident in the force-fed animals, weanling or adult, nor were they seen in adult rats fed ad lib. It should be noted that whereas the ad lib.-fed rats were fed for $2 \mathrm{I} \mathrm{d}$ before killing them, the forcefed rats were killed after $5 \mathrm{~d}$. Since these lesions appeared only in ad $l i b$.-fed weanling rats but not in ad lib.-fed adults, it appears, therefore, that for the production of dermatoses or oedema associated with protein deficiency in the rat the age of the animal is crucial.

Some of the rats (weanling or adult) on protein-deficient diets exhibited unilateral keratinization of the cornea with eventual atrophy of the eyeballs. These eye lesions usually became evident from about the I2th to the $5_{5}$ th day of feeding and were not therefore seen in rats force-fed for $5 \mathrm{~d}$. 
On laparotomy it was observed that in some of the rats on protein-deficient diets the stomach and small intestine were distended and that about $20 \%$ of them had petechial gastric ulcers entirely sited on the glandular stomach.

Rats on protein-deficient diets also displayed some behavioural and neurological abnormalities. They were more irritable than the rats fed on laboratory chow or on a high-protein diet. Fighting in these groups occasionally occurred, leading to deaths and cannibalism which resulted in cancellation of experiments as protein from the carcass would alter the expected protein intake. Towards the terminal stages the animals often assumed bizarre postures and gaits: the legs appeared stiff, the back arched, and often the animals preferred to stand on their toes. Walking or running was frequently on toes and unco-ordinated. Back-cycling was common.

\section{Histological findings in the liver}

Fat stains revealed very little fat in the livers of the control rats and of rats on the high-protein diet, whether fed forcibly or ad lib. In contrast, the livers of rats force-fed with the protein-deficient diets showed severe fatty infiltration which involved the entire lobules. The fat globules within the central zone were smaller in size than those on the periphery, indicating the peripheral origin of the infiltration. In rats given the protein-deficient diets $a d$ lib., the livers displayed fine but extensive fat-staining cells that were mainly peripheral in distribution.

When rats on the low-protein and the protein-free diets were rehabilitated on a normal laboratory rat chow all the above pathological lesions (with the exception of the eye lesions) and behavioural abnormalities virtually disappeared within I4-2I d.

\section{Gastro-intestinal histamine concentration}

In force-fed rats, irrespective of the protein level of the diet, ruminal histamine concentration was unaltered; in the glandular stomach there was a slight reduction (Fig. $4 a$ ). In contrast, when rats were fed $a d l i b$. those on the low-protein and proteinfree diets showed large and significant $(P<0.001)$ increases in histamine concentrations in both the glandular and the ruminal portions of the stomach (Fig. $4 b$ ). Rats fed on the high-protein diet did not show any significant changes in gastric histamine concentrations.

When the rats on the protein-deficient regimens were rehabilitated on a normal laboratory chow the gastric histamine concentrations fell to normal within $\mathrm{I}_{4} \mathrm{~d}$ (Fig. $4^{b}$ ).

In control rats the ileal histamine concentration was found to be $12 \cdot 1 \pm 4 \cdot I \mu \mathrm{g} / \mathrm{g}$ tissue. No significant change in ileal histamine concentration was produced by any of the dietary regimens, whether the rats were fed forcibly or $a d l i b$. 

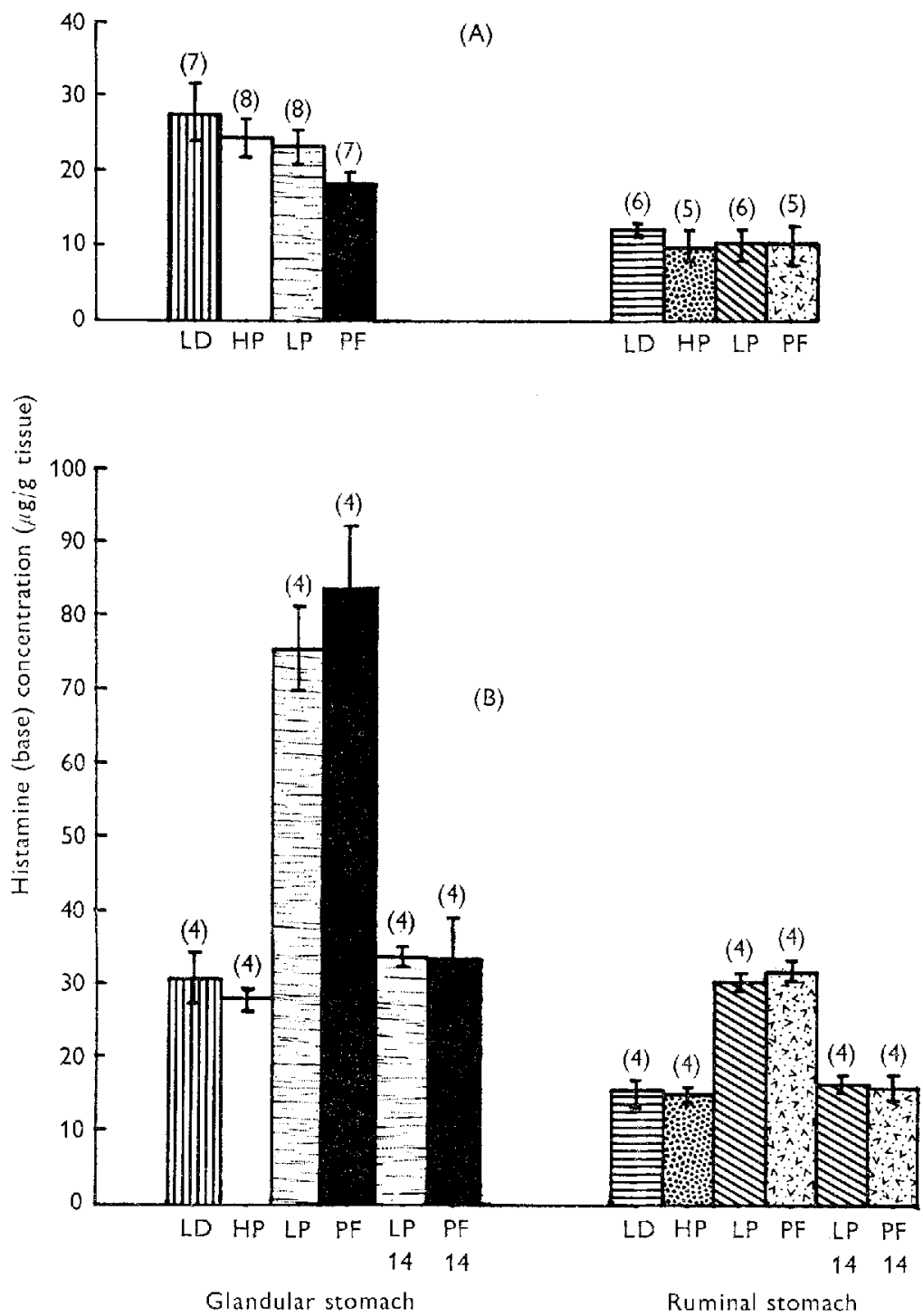

Fig. 4. Effects of diets of different protein content on gastric histamine concentrations in force-fed rats (A) and ad lib. fed rats (B). The number of determinations per nutritional group is shown in parentheses. 'The vertical bars represent the standard errors of the mean. LD, laboratory diet (control); HP, high-protcin; LP, low-protein; PF, protein-free; I.P/I 4, LP rehabilitated I $4 \mathrm{~d} ; \mathrm{PF} / \mathrm{I} 4, \mathrm{PF}$ rehabilitated I4 d.

\section{DISCUSSION}

There are reported failures to simulate kwashiorkor syndromes in experimental animals by feeding them ad lib. on diets very low in protein or on protein-free diets (Platt et al. 1964; Kirsch, Brock \& Saunders, 1968), the reason suggested being depressed food intake.

The method used by many workers in calculating food intake where food consumption is based on animal units (g food/rat) (Sidransky \& Rechcigl, r962; Sidransky \& Faber, I958; Beaton, Feleki \& Stevenson, 1965; Kirsch, Brock \& Saunders, 1968) is 
questionable in protein-malnutrition experiments. Protein deficiency depresses growth (Fig. I) and since food intake must fall when growth is depressed - unless there is abnormal metabolism or absorption - it seems that the more appropriate method for determining food intake in protein-malnutrition experiments is to relate it to animal body-weight rather than to animal units. Thus in Fig. $2(a)$ the amount of food eaten per rat on laboratory chow or the high-protein diet increased with age because the diets contained adequate protein to sustain growth, which in turn demanded increased food intake. The amount of food consumed per rat on the low protein or the protcinfree diet gradually declined with age because these animals, deprived of amino acids, were losing weight and the food intake followed apace. In Fig. $2(b)$, where the food intake is related to animal body-weight, the rates of food intake of the rats on the high-protein diet and of those on the low-protein and protein-free diets appear indistinguishable from one another; this is so because the effect of the dicts on bodyweight has been eliminated by this method of calculating food consumption.

The significant difference between the food intakes of the rats on the laboratory diet and of those on the high-protein diet (Fig. 3) was probably due to some difference in palatability. The laboratory diet had a higher fibre content and the maize oil in the experimental diets tended to make them feel greasy. 'Texture may influence the acceptability of a foodstuff to rats and storage resulting in the souring of one or other of the components may affect the diet's palatability. The reason why those rats on the low-protein diet ate less than those on the protein-free diet is not known, but it was a consistent finding.

The diets used in these studies were not isocaloric and consequently the variations in calorie intake within the experimental groups were not in the same proportion as the variations in food intake. However, calculations based on the results of $\mathrm{Njaa}$ ( ${ }_{9} 9_{5}$ ) showed that rats weighing $50-60 \mathrm{~g}$ required between $4 \mathrm{I}$ and $47 \mathrm{kcal} / \mathrm{roO} \mathrm{g}$ bodyweight daily for maintenance, and growing rats did not need significantly more. Beaton et al. (1965) obtained satisfactory growth in rats with a daily calorie intake of about $35 \mathrm{kcal} / \mathrm{I} 00 \mathrm{~g}$ body-weight. These values agree with the range of calorie intake obtained for rats in all the dietary regimens used in the present work (Fig. 3).

Children with the basic kwashiorkor syndromes often present with retarded growth, muscular wasting, oedema, fatty infiltration of the liver, various dermatoses and changes in hair colour, texture, and quantity. In addition there are often some psychological disturbances - for example, petulant apathy. Some of these symptoms have been reproduced in the present work by feeding rats, both weanling and adult on low-protein or protein-free diet, forcibly or ad lib. It is of interest to observe that, apart from fatty liver, the symptoms produced were more pronounced in rats fed ad lib. for $2 \mathrm{I} \mathrm{d}$ and that oedema and skin lesions were demonstrated only in the weanling rats fed for $2 \mathrm{I} d$ ad lib. It is probable that oedema and skin lesions could have been produced in the force-fed weanling rats if the experimental conditions had permitted a feeding period longer than the $5 \mathrm{~d}$ used. It is not clear why weanling rats seemed to be more susceptible to certain deleterious effects of protein malnutrition but it is in accord with observations in human beings that children are more adversely affected by protein malnutrition than adults. 
The observed increase in gastric histamine concentration in rats subjected to protein malnutrition is significant and carries potential implications. Mammalian histamine is endogenous in origin (Kahlson \& Rosengren, 1968), being formed by the intracellular decarboxylation of histidine by the enzyme histidine decarboxylase (Schayer, 1952). Because the precursor of histamine is an amino acid a decrease in tissue histamine in conditions of protein malnutrition rather than a normal or elevated concentration would have appeared more likely. Gastric histamine has been found to occur in close proximity to the parietal cells of the fundic stomach (Hakanson \& Owman, 1966) and in the Rhesus monkey fed on a protein-deficient diet all three types of secretory cells of the gastric mucosa are reduced in number (Deo \& Ramalingaswami, 1964). Atrophic morphological changes of the gastro-intestinal tract in protein malnutrition have also been reported in both animals and man (Platt et al. 1964). Histidine is an essential amino acid to the young of many animal species - rat (Rose \& Cox, I924; Cox \& Rose, 1926; Rose, Oesterling \& Womack, 1948), mouse ('Tottcr \& Berg, 1939), chick (Almquist, I947), pig (Rechcigl, Loosli, Horvath \& Williams, 1956) and man (Snyderman, Boyer, Roitman, Holt \& Prose, 1963) - and a pertinent question is: where is the source of histidine for the high synthesis of gastric histamine in these protein malnourished rats, especially in those fed on a protein-free diet? It is important to remember that whereas the concentrations of most free amino acids, notably the essential amino acids, in the plasma of children with kwashiorkor are generally low (Holt, Snyderman, Norton, Roitman \& Finch, I963; Arroyave, Wilson, de Funes \& Béhar, 1962; Vis, I964; Edozien \& Obasi, 1965; Saunders, Truswell, Barbezat, Wittman \& Hansen, 1967 ), the plasma concentration of histidine is frequently raised (Saunders et al. 1967). Similar amino acid profiles have also been observed in protein-malnourished rats (Kirsch, Brock \& Saunders, I968). When an animal is subjected to severe protein deprivation its existence is preserved, for a shorter or longer length of time depending on the extent of protein restriction, by feeding on its body proteins. Circumstantial evidence thercfore strongly supports the view that it is through this autophagy that amino acids and the enzymes are made available for the synthesis of various types of physiological materials vital to the survival of the animal when protein intake is severely deficient. Thus, not only is the gastric histamine concentration increased by protein malnutrition as reported here, but the brain contents of histamine, 5-hydroxytryptamine, acetylcholine and noradrenaline, as well as concentrations of 5 -hydroxytryptamine of the gastro-intestinal tract and adrenaline of the adrenal glands, are well preserved in protein-malnourished rats (unpublished results). These are all very active physiological substances which, by virtue of either their amino acid origin or their anabolizing enzymes, should theoretically be expected to present low-tissue values in protein malnutrition. Waterlow (1962) has shown in his review that the degree of preservation of most enzyme systems in protein malnutrition is more remarkable than the extent of the loss of the others.

In severe kwashiorkor there is a metabolic block betwcen histidine and formiminoglutamic acid as a result of a deficiency of the enzyme urocanase (Dean \& Whitehead, 1963; Whitehead, 1964). Similarly, deficiencies of liver histidine ammonia-lyase and urocanase occur in experimental protein malnutrition in animals (Rajagopal Rao, 
Deodhar \& Hariharan, I965). One of the ultimate results of these events will be the diversion of histidine to its other metabolic pathways, and it is therefore conceivable that in protein malnutrition more histidine is presented to histidine decarboxylase for conversion to histamine. If this happens, the gastric mucosa with its exceedingly high histidine decarboxylase activity (Kahlson et al. 1964; Maudsley, Radwan \& West, 1967) and very low histaminase (diamine oxidase) activity (Best \& McHenry, I930; Rose, Karady \& Browne, I940; Dworetzky \& Code, 195I) is more favourably placed to utilize this substrate than the ileum which is exceedingly low in histidine decarboxylase but comparatively rich in histaminase (Rose et al. 1940; Dworetzky \& Code, 1951). Histidine decarboxylase of the gastric mucosa is an adaptive enzyme for it is capable of rapid changes in activity or concentration (Kahlson et al. 1964) and its bchaviour in protein malnutrition is not known. This is under investigation at present. Code ( I $^{6} 6_{5}$ ) has pointed out that the gastric mucosa appears to offer a barrier to the loss of histamine and aids in its conservation in the body. In the force-fed groups of rats some reductions of gastric histamine (Fig. $4 a$ ) were obtained irrespective of the dietary protein intake. It is probable that severe stomach distension produced by rather high volumes of food emulsions contributed to these reductions. Stomach distension with food mobilizes gastric histamine (Kahlson et al. 1964). It is also probable that had the experimental conditions permitted force-feeding for longer periods, protein-deficient diets would have produced results similar to those obtained with ad lib. feeding.

Histamine is a gastric secretagogue and many workers agree that stimulation of gastric acid juice is a physiological function of this amine (Babkin, I938; Code, I965). Ulceration has been reported in patients treated with prolonged courses of intravenous histamine for histamine cephalalgia, Ménières syndrome or multiple sclerosis (McHardy \& Browne, I944; Kirsner, I957). In the present work some of the rats on the protein-deficient dicts developed gastric ulcers. Widdowson (1968) and Grimble \& Whitehead (1969) have reported gastric erosions in pigs on low-protein diets, therefore there is reason to speculate that increased gastric histamine in conditions of low dietary protein might be the aetological factor in these ulcerations.

It is appreciated that the application to the human beings of experimental results obtained with animals is a difficult exercise. However, in many instances results obtained in experimental protein malnutrition in animals have been found to apply in man (Kirsch, Saunders \& Brock, 1968). No case of gastric ulceration has been reported in association with kwashiorkor. However, in view of the very low gastric acid titre in children (Vanzant, Alvarez, Eusterman, Dunn \& Berkson, 1932), this is not altogether surprising. What may be important, however, is the probable implication of gastric histamine in the pattern of gastric ulcer incidence (which bears an inverse relation to dietary protcin content) (Konstam, I954, I958) in the adult population of areas of the world where nutritional protein deficiency is endemic.

My grateful thanks go to Professor M. J. Rand, in whose department this work was concluded, and for his reading through the manuscript. I am grateful to Professor V. A. Oyenuga of the Department of Animal Science, University of Ibadan, for the 
analysis of the experimental diets and to Professor H. D. Attwood of the Department of Pathology, Austin Hospital, University of Melbourne, for the preparation of the liver samples for histological examination. I also thank Mr Olufemi Sanyaolu for his invaluable laboratory assistance. I am indebted to Mrs R. I. Downing, Trustee, Howard Norman Trust of Australia, for her financial assistance. This work was partly supported by a grant from The West African Council for Medical Research and to this body I express my gratitude.

\section{REFEREN CES}

Adamstone, F. B. \& Spector, H. (1950). Archs Path. 49, I73.

Almquist, H. J. (1947). F. Nutr. 34, 543 .

Arroyave, G., Wilson, D., de Funes, C. \& Béhar, M. (1962). Am. F. clin. Nutr. 1r, 517.

Babkin, B. P. (1938). Can. med. Ass. F. 38, 42 r.

Beaton, J. R., Feleki, V. \& Stevenson, J. A. F. (1965). Can. F. Physiol. Pharmac. 43, 225.

Best, C. H. \& McHenry, E. W. (1930). F. Physiol., Lond. 70, 349.

Code, C. F. (1965). Fedn Proc. Fedn Am. Socs exp. Biol. 24, I3I I.

Cox, G. J. \& Rose, W. C. (1926). F. biol. Chem. 68, 78 r.

Dean, R. F. A. \& Whitehead, R. G. ( $\left(96_{3}\right)$. Lancet i, 188.

Deo, M. G. \& Ramalingaswami, V. (1964). Gastroenterology 46, г67.

Dworetzky, M. \& Code, C. F. (I95I). Am. F. Physiol. 166, 462.

Edozien, J. C. \& Obasi, M. E. (I965). Clin. Sci. 29, r.

Grimble, R. F. \& Whitehead, R. G. (1969). Br. F. Nutr. 23, 791.

Hakanson, R. \& Owman, C. (1966). Biochem. Pharmac. 15, 489 .

Holt, L. E. Jr, Snyderman, S. E., Norton, P. M., Roitman, E, \& Finch, J. (1963). Lancet ii, I 343.

Jones, J. H. \& Foster, C. (1942). F. Nutr. 24, 245 .

Kahlson, G. \& Rosengren, E. (1968). Physiol. Rev. 48, I55.

Kahlson, G., Rosengren, E., Svahn, D. \& 'Thunberg, R. (1964). F. Physiol., Lond. r74, 400.

Kirsch, R. E., Brock, J. F. \& Saunders, S. J. (1968). Am. F. clin. Nutr. 21, 820.

Kirsch, R. E., Saunders, S. J. \& Brock, J. F. (1968). Am. F. clin. Nutr. 21, r225.

Kirsner, J. B. (1957). Ann. intern. Med. 47, 666.

Konstam, P. G. (I954). Lancet ii, I039.

Konstam, P. G. (1958). Schweiz. Z. Path. Bakt. 2r, 229.

Lambert, R. (1965). Surgery of the Digestive System in the Rat. Springfield, I11.: C. C. Thomas.

McCance, R. A. \& Widdowson, E. M. (I966). Lancet ii, 158.

McHIardy, G. \& Browne, D. C. (1944). Gastroenterology 2, 345 .

Maudsley, D. V., Radwan, A. G. \& West, G. B. (r967). Br. F. Pharmac. Chemother. 3I, 3I3.

Njaa, L. R. (I965). Br. F. Nutr. I9, 443.

Parratt, J. R. \& West, G. B. (1957). F. Physiol., Lond. 137, 169.

Platt, B.S., Halder, K. \& Doell, B. H. (Ig62). Proc. Nutr. Soc. 21, vi.

Platt, B. S., Heard, C. R. C. \& Stewart, R. J. C. (I964). In Mammalian Protein Metabolism Vol. 2, p. 445 [H. N. Munro and J. B. Allison, editors]. New York: Academic Press.

Rajagopal Rao, D., Deodhar, A. D. \& Hariharan, K. (1965). Biochem. F. 97, 3I I.

Recheigl, M. Jr, Loosli, J. K., Horvath, D. J. \& Williams, H. H. (1956). J. Nutr. 6o, 6r9.

Rose, W. C. \& Cox, G. J. (1924). F. biol. Chem. 6r, 747 .

Rose, B., Karady; S. \& Browne, J. S. L. (r940). Am. F. Physiol. r29, 219.

Rose, W. C., Oesterling, M. J. \& Womack, M. (1948). F. biol. Chem. 176, 753.

Samuels, L. T., Goldthorpe, H. C. \& Dougherty, T. F. (195I). Fedn Proc. Fedn Am. Socs exp. Biol. Io, 393 .

Saunders, S. J., Truswell, A. S., Barbezat, G. O., Wittman, W. \& Hansen, J. D. L. (1967). Lancet ii, 795 .

Schayer, R. W. (1952). F. biol. Chem. I99, 245.

Shay, H. \& Gruenstein, M. (1946). F. Lab. clin. Med. 31, 1384.

Sidransky, H. \& Faber, E. (1958). Archs Path. 66, 119.

Sidransky, H. \& Rechcigl, M. Jr (1962). F. Nutr. 78, 269.

Snyderman, S. E., Boyer, A., Roitman, E., Holt, L. E. Jr \& Prose, P. H. (1963). Pediatics, Springfield 3т, 786.

Spector, H. \& Adamstone, F. B. (1950). \%. Nutr. 40, 213.

Totter, J. R. \& Berg, C. P. (1939). F. biol. Chem. 127, 375. 
British Fournal of Nutrition, Vol. 28, No. I

Plate I
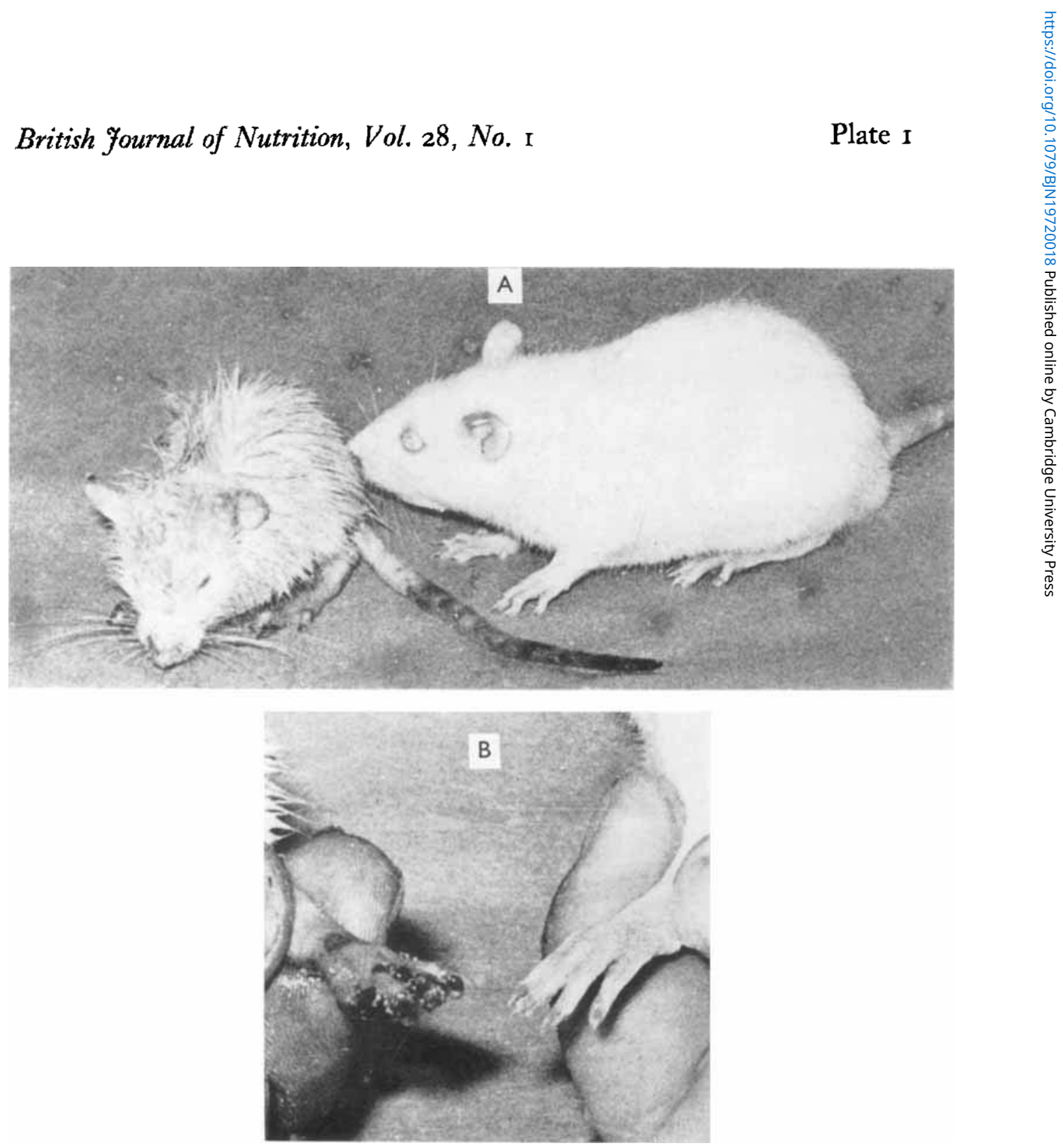

L. I. L. NDIKA

(Facing p. I65) 
Van Pilsum, J. F., Speyer, J. F. \& Samucls, I. T. (1957). Archs Biochem. Biophys. 68, 42.

Vanzant, F. R., Alvarez, W. C., Eusterman, G. B., Dunn, H. L. \& Berkson, J. (1932). Archs intern. Med. 49, 345.

Vis, H. (1964). Aspects et mechanismes des hyperaminoaciduries de l'enfance-Recherches sur le Kwashiorkor, le rachitisme commun et le scorbut. Brussels: S. A. Arscia.

Waterlow, J. C. (1962). Proc. R. Soc. Med. B. 156, 345.

Whitehead, R. G. (1964). Clin. Sci. 26, 27 I.

Widdowson, E. M. (1968). In Calorie Deficiencies and Protein Deficiencies p. 225 [R. A. McCance and E. M. Widdowson, editors]. London: J. and A. Churchill.

\section{EXPLANATION OF PLATE}

Overt appearance of weanling rats fed on a high-protein diet $(A$, right) or a low-protein diet $(A$, left), and the paws of weanling rats fed on a high-protein $\operatorname{diet}(B$, right) or a low-protein diet $(B$, left). Note the oedema and the ulcerative changes in the paw of the protein-malnourished rat. The rats were fed $a d$ lib. 